\title{
Peningkatan Produksi dan Kualitas Produk Unggulan Kerupuk Ikan Desa Pangkahkulon Kecamatan Ujung Pangkah-Gresik Jawa Timur
}

\author{
Increasing Production and Quality of Fish Crackers Leading Products in Pangkahkulon \\ Village, Ujung Pangkah-Gresik District, East Java
}

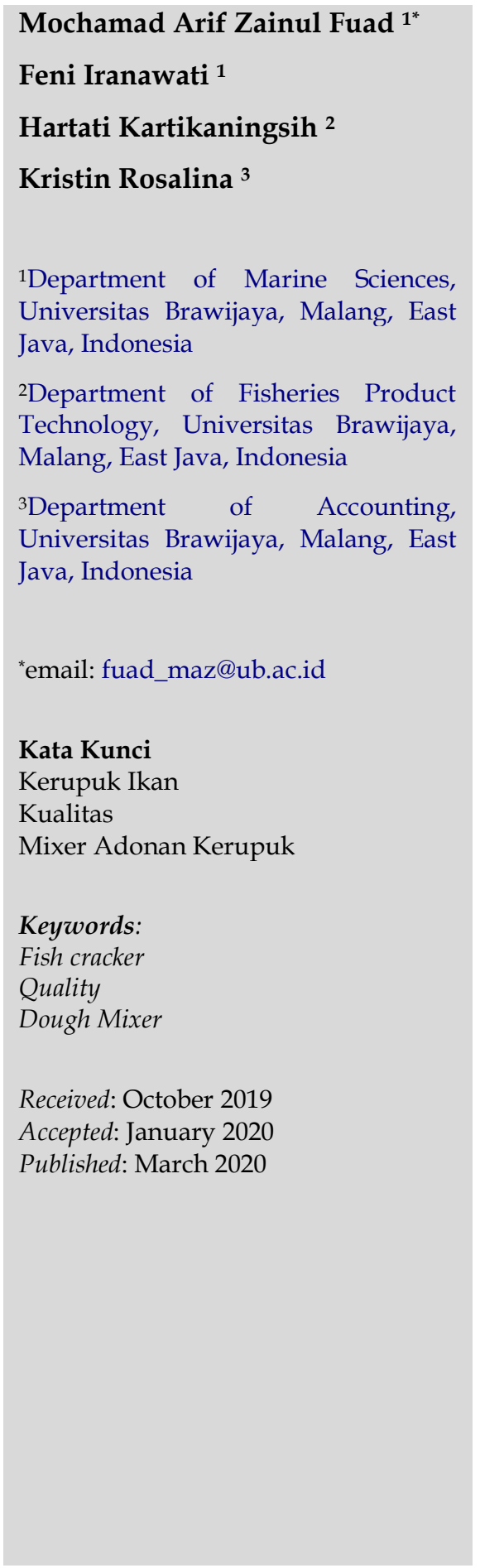

\begin{abstract}
Abstrak
Desa Pangkahkulon merupakan desa pesisir di Kecamatan Ujung Pangkah, Gresik dengan lebih dari 70\% dari luas wilayahnya adalah tambak budidaya ikan dan udang. Untuk meningkatkan ekonomi rumah tangga, banyak nelayan yang mendirikan industri rumah tangga (IRT) dalam mengolah hasil perikanan. Berdasarkan hasil Pemetaan Potensi Desa Pangkahkulon, jumlah usaha produk perikanan mencapai 98 unit. Usaha rumah tangga tersebut mayoritas merupakan industri kerupuk ikan yaitu sebanyak 67 unit. Kegiatan Program Pengembangan Desa Mitra (PPDM) tahun pertama ini bertujuan untuk melakukan pemberdayaan masyarakat melalui pengembangan dan peningkatan produksi serta daya saing produk unggulan desa. Oleh karena itu, berdasarkan potensi yang telah dipetakan dan diskusi dengan aparat Desa Pangkahkulon, maka diputuskan bahwa produk unggulan Desa Pangkahkulon yang akan diangkat yaitu kerupuk ikan. Secara umum kegiatan yang dilakukan tahun pertama ini adalah peningkatan produksi dan daya saing IRT kerupuk ikan yang salah satunya melalui bantuan alat produksi. Alat sarana produksi yang dihibahkan kepada IRT berupa 2 unit mixer pengaduk dan 1 unit pemotong adonan kerupuk otomatis. Alat ini dihibahkan untuk menjawab permasalahan utama yang dialami oleh IRT yaitu hasil adonan kerupuk yang tidak konsisten karena selama ini pembuatan adonan masih dilakukan dengan tangan. Bantuan alat melalui program PPDM mampu meningkatkan kapasitas produksi sampai dengan $35 \%$.
\end{abstract}

\begin{abstract}
Pangkahkulon Village is a coastal village in Ujung Pangkah District, Gresik with more than $70 \%$ of its area being fish and shrimp farming ponds. To improve the household economy, many fishermen set up home industries (IRT) in processing fishery products. Based on the results of the Pappingkulon Village Potential Mapping, the number of fishery product businesses reached 98 units. The majority of these household businesses are the fish cracker industry with a total of 67 units. The first year of the Mitra Desa Development Program (PPDM) aims to empower communities through the development and improvement of the production and competitiveness of superior village products. Therefore, based on the mapped potential and discussion with Pangkahkulon Village officials, it was decided that the superior product of Pangkahkulon Village to be appointed was fish crackers. In general, the activities carried out in the first year were to increase production and competitiveness of IRT fish crackers, one of which was through the help of production equipment. The production facilities which were donated to IRT were in the form of two units of the mixer and one unit of automatic cracker dough cutter. This tool was granted to answer the main problem experienced by IRT, which is the inconsistency of cracker dough results because so far the making of the dough is still done by hand. Tool assistance through the PPDM program is able to increase production capacity by up to $35 \%$.
\end{abstract}




\section{PENDAHULUAN}

Desa Pangkahkulon, merupakan salah satu desa dari tiga belas desa yang termasuk dalam wilayah Kecamatan Ujung Pangkah. Menurut Badan Pusat Statistik (BPS) Kabupaten Gresik (2016), desa ini memiliki luas wilayah kurang lebih $22 \mathrm{~km}^{2}$ yang terbagi menjadi empat dusun. Desa Pangkah kulon secara administrasi masuk dalam kecamatan ujung Pangkah Kabupaten Gresik. Batas desa sebelah utara adalah laut jawa, sebelah selatan adalah Desa Kebonagung dan Desa Pangkah Wetan, sedangkan sebelah barat dengan Desa Banyuurip.

Pada tahun 2017, lebih dari 70\% dari luas wilayah Desa Pangkahkulon merupakan tanah tambak. Jumlah penduduk di desa ini 8,268 jiwa sehingga kepadatan penduduknya sebesar 380 orang $/ \mathrm{km}^{2}$, dan sebagian besar (kurang lebih 66\%) berusia diantara 17-59 tahun (usia produktif). Dengan memperhatikan jumlah penduduk yang cukup padat dan luasan wilayahnya sebagian besar sebagai tambak, maka program pengembangan pembangunan di desa ini yang sesuai adalah pengembangan di bidang perikanan, baik dari budidaya, pengolahan dan pemasaran hasil perikanan. Berdasarkan hasil kegiatan Pemetaan Potensi Desa Pangkah Kulon yang didanai dengan program Doktor Mengabdi UB tahun 2017, jumlah UKM produk perikanan mencapai 98 UKM/ Industri Rumah Tangga (Iranawati et al., 2017) yang didominasi oleh UKM kerupuk ikan sebanyak 68 UKM.

Kerupuk ikan merupakan salah satu makanan ringan yang sangat populer di Indonesia (Agustina \& Saputro, 2018). Produk pangan ini terbuat dari beberapa bahan dengan basis karbohidrat tepung seperti sagu, tapioka, jagung, beras yang dibuat adonan dan mengalami proses gelatnisasi, dipotong tipis, dikeringkan dan dipanaskan pada suhu tinggi (Pakpahan \& Nelinda, 2019). Proses produksi kerupuk ikan yang dilakukan oleh mitra UKM mulai dari pemilihan bahan sampai dengan pengemasan dan pemasaran umumnya dilakukan sendiri oleh mitra. Pembuatan adonan sampai dengan penjemuran kerupuk ada yang dilakukan dengan secara manual maupun dengan menggunakan mesin.

Berdasarkan survey, wawancara dan pengamatan kegiatan produksi yang di lakukan pada beberapa UKM kerupuk ikan disimpulkan bahwa sebagain besar proses produksi kerupuk ikan belum menerapkan standar mutu keamanan pangan yang telah ditentukan pemerintah melalui Peraturan Kepala Badan POM No. HK.03.1.23.04.12.2206 Tahun 2012 tentang Cara Produksi Pangan Yang Baik Untuk Industri Rumah Tangga (CPPB-IRT). Temuan yang didapatkan saat survey antara lain yaitu terkait permasalah peralatan produksi, kualitas adonan yang tidak seragam, bangunan dan fasilitas produksi, suplai air, fasilitas dan kegiatan higiene dan sanitasi serta penggunaan Bahan Tambahan Pangan (BTP) yang tidak sehat. Permasalahan keamanan pangan dan hygiene ini juga umum ditemukan di pelaku UKM produk perikanan lainnya seperti kerupuk ikan (Fuad \& Sartimbul, 2017; Waluyo \& Fuad, 2014), Ikan Asap (Fuad et al., 2019), petis ikan (Hasanah et al., 2018), dan Pindang ikan (Thaheer et al., 2015).

Oleh karena itu kegiatan tahun pertama pada Program Pengembangan Desa Mitra (PPDM) ini salah satunya adalah penyuluhan keamanan pangan dan pemberian bantuan alat produksi berupa Mixer adonan kerupuk ikan dengan tujuan agar adonan yang dihasilkan memiliki kualitas yang seragam, peningkatan produktifitas, dan proses produksi yang semakin cepat. Sasaran dari kegiatan pengabdian masyarakat ini adalah 3 anggota kelompok UKM / IRT kerupuk ikan yang ada di Desa Pangkahkulon Kecamatan Ujung Pangkah Kabupaten Gresik. 


\section{METODOLOGI}

Kegiatan pengabdian masyarakat program Pengembangan Desa Mitra ini dilakukan dengan pendekatan partisipatif. Pendekatan ini secara langsung mengutamakan peran mitra dalam pelaksanaan kegiatan yang dimulai dari proses identifikasi permasalahan, pencarian solusi atas masalah, pelaksanaan solusi yang telah disepakati bersama sampai dengan evaluasi dan monitoring kegiatan.

Langkah langkah pelaksanaan kegiatan ini adalah sebagai berikut:

1. Diskusi awal dengan Perwakilan Mitra

2. Sosialisasi kegiatan

3. Identifikasi permasalahan Mitra

4. Diskusi perumusan permasalahan utama dan alternatif solusi yang bisa dilakukan

5. Pelaksanaan kegiatan berdasarkan solusi yang telah disepakati

6. Evaluasi dan monitoring kegiatan

Indikator keberhasilan program PPDM ini terdiri dari 2 komponen utama yaitu indikator kualitatif dan kuantitatif. Indikator kualitatif berupa peningkatan pengetahuan dan ketrampilan khalayak sasaran tentang materi yang diberikanan oleh pelaksanan kegiatan. Sedangkan indikator kuantitatif berupa meningkatnya produksi UKM kerupuk ikan.

\section{HASIL DAN PEMBAHASAN}

Diskusi Awal dengan Perwakilan Mitra

Diskusi awal ini dilakukan untuk merancang tahapan pelaksanaan kegiatan PPDM yang akan dilakukan. Mitra yang diikutsertakan dalam diskusi adalah perwakilan UKM kerupuk ikan, Perwakilan Perangkat Desa, dan Fasilitator Lapangan. Kehiatan ini dilakukan di Balai Desa Pangkahkulon pada tanggal 11 Juni 2019.

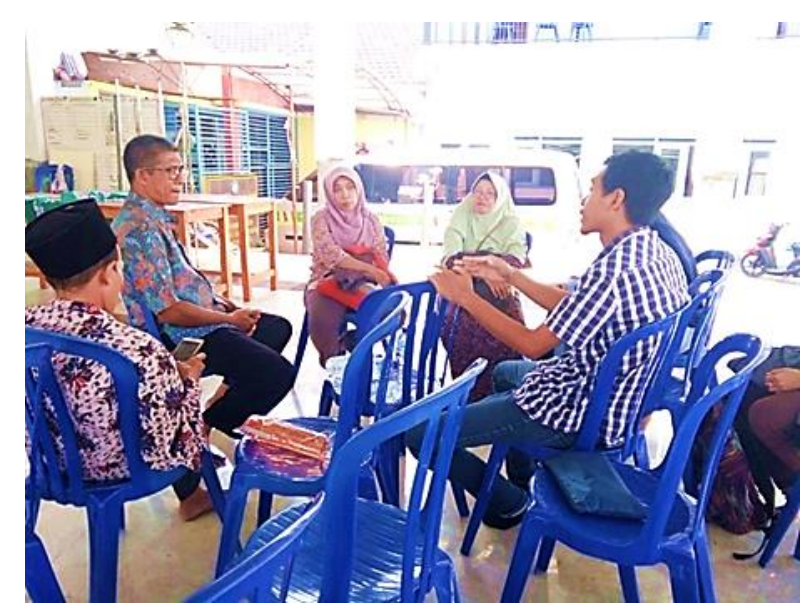

Gambar 1. Diskusi awal dengan perwakilan mitra

\section{Sosialisasi Kegiatan}

Sosialisasi program ini diberikan kepada mitra dengan tujuan agar mitra mengetahui tujuan, sasaran, dan rangkaian kegiatan yang akan dilakukan. Sosialisasi dilaksanakan pada tanggal 8 Agustus 2019 kepada perangkat desa, perwakilan UKM sebanyak 25 orang, Badan Permusyawaratan Desa (BPD) dan Tokoh masyarakat Desa Pangkahkulon.

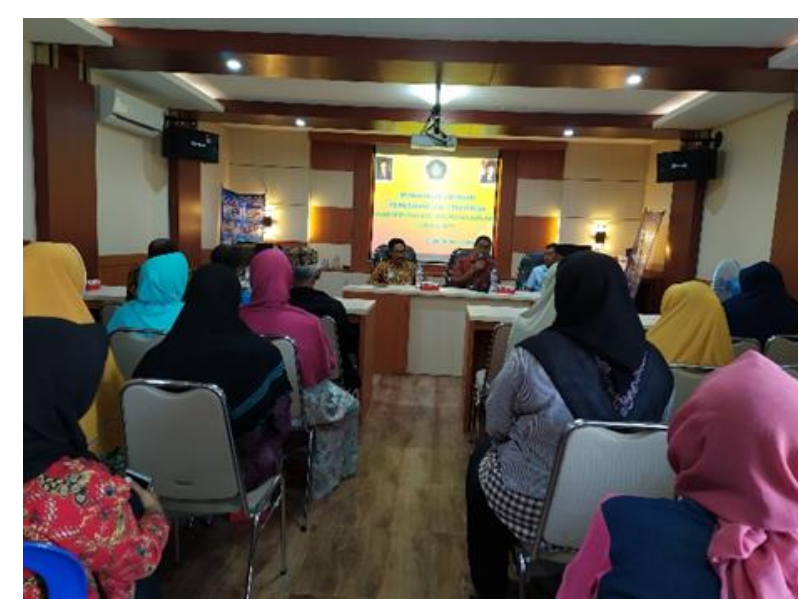

Gambar 2. Sosialisasi Kegiatan PPDM

\section{Identifikasi Permasalahan Mitra}

Di Desa Pangkahkulon terdapat 67 industri rumah tangga (IRT) yang menghasilkan kerupuk ikan berbagai bentuk dan ukuran yang tersebar di 4 dusun yaitu Dusun Kalingapuri, Krajan 1, Krajan 2, dan Druju. Masing masing IRT tersebut mampu menghasilkan 5-40 kg kerupuk ikan setiap harinya. Berdasarkan sensus 
UKM dan wawancara setidaknya ditemui beberapa kendala yang dialami oleh IRT kerupuk ikan yang ada di desa ini.

Permasalahan khusus aspek produksi pada IRT kerupuk ikan yang didapatkan pada saat diskusi, wawancara, dan, survey ke UKM adalah:

1. Pembuatan adonan secara manual sehingga kapasitas produksi rendah

Sebagian besar IRT kerupuk ikan di Pangkahkulon mengemukakan bahwa selama ini mereka membuat adonan kerupuk secara manual dengan tenaga manusia (Gambar 3). Dalam satu hari maksimal mampu membuat adonan sebanyak $15-20 \mathrm{~kg}$ dengan lama pengerjaan 3-4 jam dalam 4x pembuatan. Masing-masing pembuatan adalah $5 \mathrm{~kg}$. Padahal pada masa-masa tertentu misalnya libutan dan hari besar agama terutama puasa dan Idul Fitri permintaan bisa mencapai $30-40 \mathrm{~kg}$, sehingga banyak pembeli yang kecewa karena kehabisan stok kerupuk.

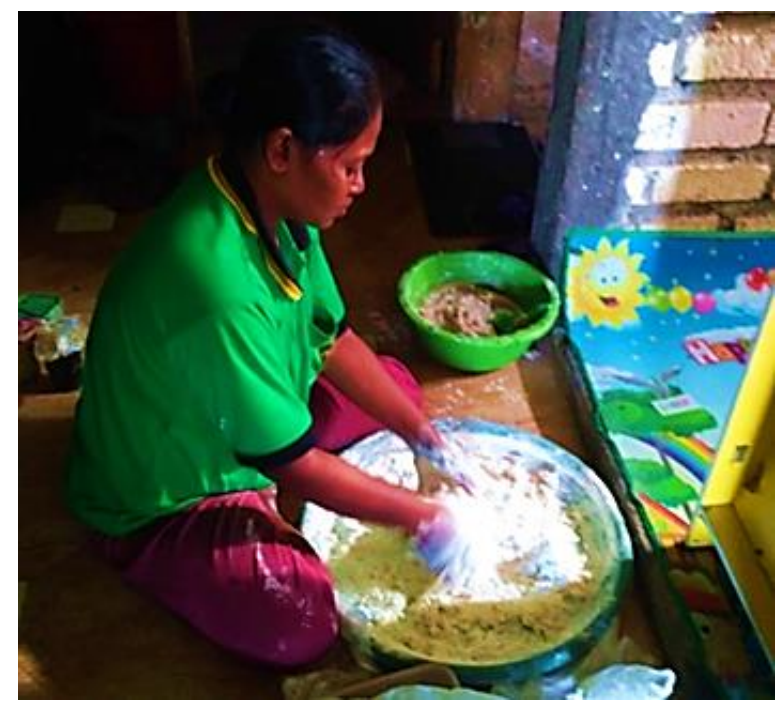

Gambar 3. Pembuatan Adonan Kerupuk Secara manual

2. Kualitas adonan kerupuk yang tidak seragam

Permasalahan ini timbul sebagai akibat dari pembuatan adonan yang masih secara manual, sehingga percampuran bahan-bahan kerupuk tidak bisa selalu sama karena sangat tergantung dari metode dan lama pengadukan oleh pekerja (Gambar $4)$.

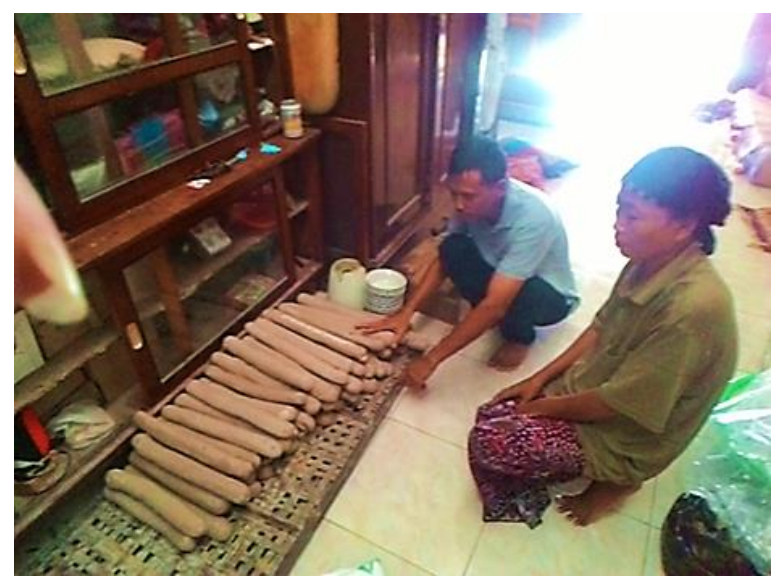

Gambar 4. Kerupuk mentah lontongan produksi Mitra Pengabdian

3. Ketebalan Irisan kerupuk yang tidak seragam

Ketebalan kerupuk yang dihasilkan oleh masing masing IRT kerupuk ikan di Desa Pangkahkulon masih banyak yang tidak seragam. Hal ini dikarenakan pemotongan adonan kerupuk masih menggunakan alat yang manual yaitu pisau pemotong yang digerakkan oleh tangan (Gambar 5). Hal ini menyebabkan ketebalan kerupuk mentah hasil potongan sangat tergantung dari keahlian dan ketepatan tangan pemotong dalam memposisikan kerupuk mentah lontongan.

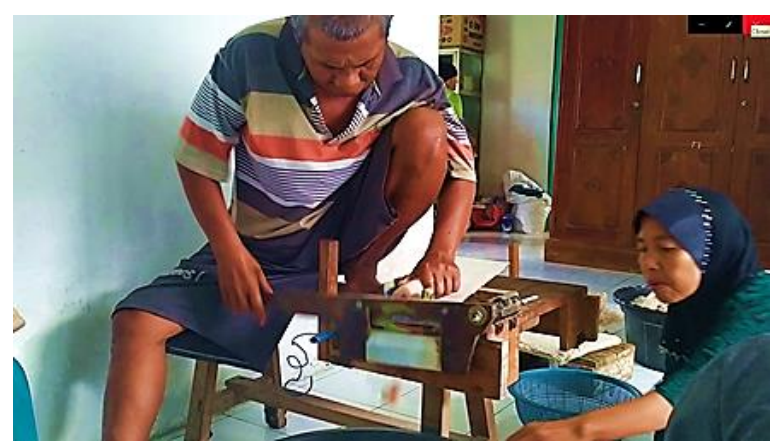

Gambar 5. Alat Pemotong kerupuk manual

Penyusunan permasalahan utama dan solusi yang ditawarkan Diskusi perumusan permasalahan utama yang bisa di selesaikan dilakukan oleh pelaksanan program PPDM 
dengan perangkat desa, perwakilan UKM dan Tokoh masyarakat. Diskusi yang dilaksanakan tersebut menghasilkan kesimpulan tentang permasalahan utama dan solusi yang ditawarkan seperti pada Gambar 4.

Pelaksanaan kegiatan berdasarkan solusi yang telah disepakati Kegiatan peningkatan produksi UKM kerupuk ikan berdasarkan kesepakatan bersama adalah dengan memberikan bantuan peralatan penunjang produksi berupa mixer dan mesin pemotong kerupuk.

1. Bantuan alat pengaduk Adonan/ Mixer

Pembuatan mesin mixer dilakukan dengan mengacu pada hasil survey yang telah dilakukan. Survey ini dilakukan untuk mengetahui kondisi awal proses produksi oleh mitra dan proses pembuatan, antara lain; Bahan bahan dan bumbu yang akan diaduk; Kapasitas mesin yang diinginkan sesuai dengan kapasitas produksi perhari yang di harapkan; Daya listrik dan calon ruangan penempatan mesin. Spesifikasi mixer yang dihibahkan adalah berbahan besi tahan karat dengan kapasitas 10-20 kg/proses dengan daya listrik 600-700 watt, $220 \mathrm{~V}$ (Gambar 6).

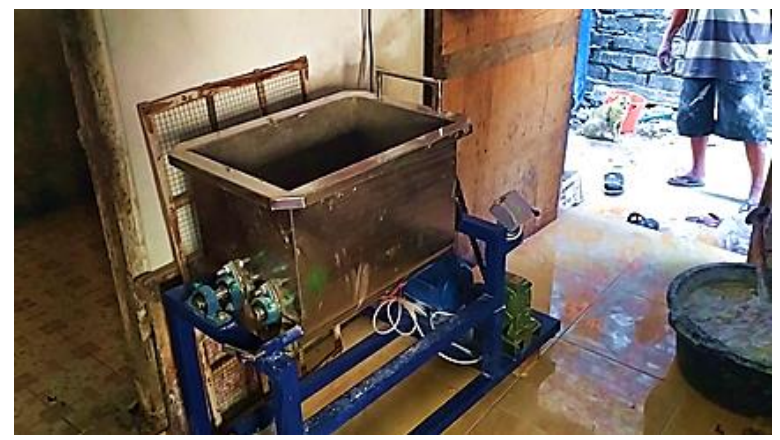

Gambar 6. Salah satu Mixer kerupuk yang dihibahkan

Dengan adanya bantuan mixer, produksi ukm mitra meningkat, waktu yang dibutuhkan untuk proses produksi berkurang, dan kualitas adonan semakin bagus dan seragam, seperti ditunjukkan pada Tabel I.
Tabel I. Produksi dan lama proses produk sebelum dan sesudah pemberian bantuan

\begin{tabular}{lcccc}
\hline \multirow{2}{*}{$\begin{array}{l}\text { Nama } \\
\text { Mitra }\end{array}$} & \multicolumn{2}{c}{ Produksi/Hari (Kg) } & \multicolumn{2}{c}{$\begin{array}{c}\text { Lama Proses } \\
\text { Produksi (Jam) }\end{array}$} \\
\cline { 2 - 5 } & $\begin{array}{c}\text { Sebelum } \\
\text { Bantuan }\end{array}$ & $\begin{array}{c}\text { Sesudah } \\
\text { Bantuan }\end{array}$ & $\begin{array}{c}\text { Sebelum } \\
\text { Bantuan }\end{array}$ & $\begin{array}{c}\text { Sesudah } \\
\text { Bantuan }\end{array}$ \\
\hline Sumitin & 15 & 25 & 3 & 2 \\
Fatimah & 40 & 50 & 5 & 3 \\
Lailiya & 15 & 25 & 3 & 2 \\
\hline
\end{tabular}

2. Bantuan Alat Pemotong Kerupuk otomatis

Alat pemotong kerupuk otomatis dihibahkan untuk mitra dalam rangka mengatasi masalah ketebalan kerupuk yang tidak konsisten. Alat yang dihibahkan ini mampu memotong 4 adonan lontongan kerupuk sekaligus sehingga dapat mempercepat proses pemotongan (Gambar 7). Jika sebelumnya dengan alat manual pemotongan dilakukan selama minimal 3 jam untuk sebanyak $40 \mathrm{~kg}$ adonan maka dengan bantuan alat ini waktu yang dibutuhkan menjadi tidak lebih dari $2 \mathrm{jam}$.

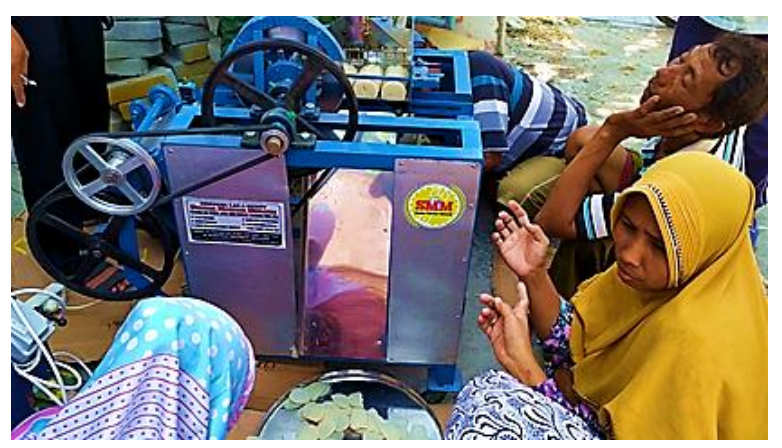

Gambar 7. Alat Pemotong Kerupuk Otomatis

Selain menghemat waktu, alat ini dapat menghasilkan potongan kerupuk yang memiliki ketebalan yang lebih konsisten daripada dipotong dengan manual. Hal ini didasarkan pada analisis ketebalan sampel kerupuk sebanyak 140 sampel dalam tiga hari produksi yaitu pada tanggal 13, 14, dan 15 September 2019. Grafik sebaran perbandingan ketebalan sampel kerupuk hasil pemotongan manual dan otomatis dapat dilihat pada Gambar 8. 


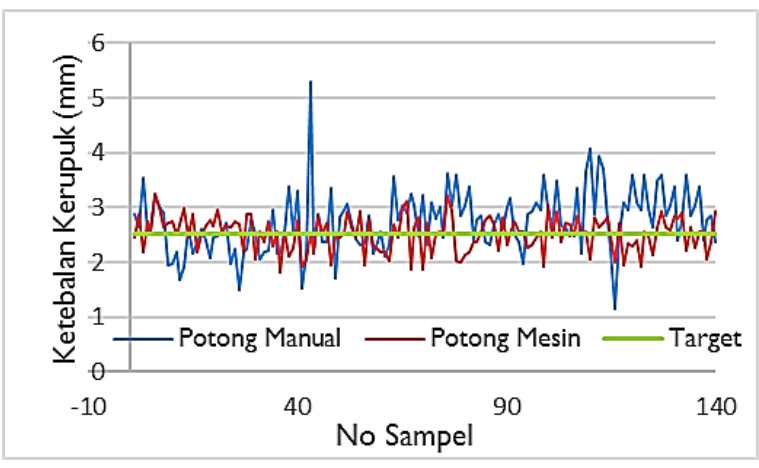

Gambar 8. Perbandingan ketebalan kerupuk

Berdasarkan Gambar 8 dapat dilihat bahwa kerupuk yang dipotong dengan alat manual memiliki ketebalan rata rata $2.74 \pm 0.56 \mathrm{~mm}$ sedangkan kerupuk dengan alat otomatis memiliki ketebalan rata rata $2.52 \pm 0.31 \mathrm{~mm}$. Berdasarkan Gambar 8 tersebut juga dapat dilihat jika kerupuk yang dipotong secara manual cenderung untuk memiliki ketebalan yang melebihi standar yang diharapkan yaitu $2.5 \mathrm{~mm}$. Selain itu juga dapat dilihat bahwa beberapa hasil potongan tersebut juga memiliki ketebalan yang sangat jauh dari standart ketebalan yang diharapkan baik lebih tipis atau lebih tebal. Ketebalan kerupuk sangat berpengaruh terhadap lama pengeringan dan daya simpan kerupuk serta kerenyahan saat digoreng. Kerenyahan kerupuk dipengaruhi oleh kadar amilopektin dan ketebalan kerupuk saat diiris. Ketebalan kerupuk ikan yang bagus umumnya antara 2-3 mm, hal ini bertujuan untuk mendapatkan potongan kerupuk yang seragam dan renyah pada saat digoreng (Mas'ud \& Veni, 2014)

Selain itu ketebalan kerupuk merupakan salah satu faktor yang sangat di pertimbangkan atau dianggap penting oleh konsumen dalam memilih kerupuk selaian harga, rasa, kemasan, tempat pembelian, bentuk, dan warna kerupuk. Konsumen kerupuk ikan lebih memilih kerupuk yang lebih tebal dikarekan ada anggapan jika kerupuk lebih tebal maka kandungan ikannya lebih banyak (Wahyuni et al., 2017).

\section{KESIMPULAN}

Kesimpulan yang didapatkan pada kegiatan ini adalah bantuan peralatan produksi berupa mixer dan pelatihan cara produksi pangan yang baik mampu meningkatkan produksi mitra sebanyak lebih kurang 35\% dan waktu produksi berkurang sekitar 1-2 jam. Ketebalan kerupuk yang dihasilkan oleh mitra semakin seragam dengan ketebalan rata rata $2.52 \pm 0.31 \mathrm{~mm}$.

\section{UCAPAN TERIMA KASIH}

Penulis mengucapkan terima kasih kepada LPPM UB dan DRPM dikti. Kegiatan ini didanai oleh Direktorat Riset dan Pengabdian Masyarakat Direktorat Jenderal Penguatan Riset dan Pengembangan Kementerian Riset, Teknologi dan Pendidikan Tinggi Dengan Perjanjian Pendanaan Pelaksanaan Program Pengabdian Masyarakat Nomor: 050/SP2H/DRPM/2019, Tanggal 18 Maret 2019. Selain itu apresisi juga ditujukan kepada Kepala Desa Pangkahkulon beserta seluruh perangkat desa yang telah membantu kelancaran kegiatan pengabdian masyarakat ini.

\section{REFERENSI}

Agustina, T., Saputro, D.D. 2018. Pengolahan Kerupuk Kulit Ikan Di Kelurahan Bulu Lor Kota Semarang. Rekayasa: Jurnal Penerapan Teknologi dan Pembelajaran. 16(1):113-118. https://doi.org/10.15294/rekayasa.v16i1.150 97

Fuad, M.A.Z., Iranawati, F., Nurdiani, R. 2019. Peningkatan Produksi dan Pengembangan Industri Rumah Tangga (IRT) Ikan Asap di Desa Banyuurip-Ujungpangkah - Gresik. JDinamika: Jurnal Pengabdian Masyarakat.4(1):5057. $\quad$ https://doi.org/10.25047/jdinamika.v4i1.1059

Fuad, M.A.Z., Sartimbul, A. 2017. Peningkatan Produksi dan Kualitas Kerupuk Ikan di Desa Pangkah Kulon Kec. Ujungpangkah. Kab. Gresik. Laporan. Malang: Universitas Brawijaya. 
Hasanah, Y.R., Ellyke, E., Ningrum, P.T. 2018. Praktik Higiene Personal dan Keberadaan Bakteri Escherichia coli Pada Tangan Penjual Petis (Studi di Pasar Anom Kecamatan Sumenep Kabupaten Sumenep). e-Journal Pustaka Kesehatan. 6(1):77-84. https://doi.org/10.19184/pk.v6i1.6770

Iranawati, F., Fuad, M.A.Z, Sartimbul, A. 2017. Pemetaan Potensi Desa Pangkahkulon, Kec. Ujung Pangkah- Kab. Gresik berbasis Sistem Informasi Geografis. Program Doktor Mengabdi. Laporan. Malang: Universitas Brawijaya.

Mas'ud, I.Z., Veni, I. 2014. Pengaruh Proporsi Puree Kacang Tunggak (Vigna unguiculata (L) Walp) dan Teri Nasi (Stolephorus commersoni) terhadap Sifat Organoleptik Kerupuk. Jurnal Tata Boga. 3(1):193-202.

Pakpahan, N., Nelinda, N. 2019. Studi Karakteristik Kerupuk: Pengaruh Komposisi Dan Proses Pengolahan. Jurnal Teknologi Pengolahan Pertanian. 1(1):28-38.

Thaheer, H., Hasibuan, S., Mumpuni, F.S. 2015. Model Resiko Keamanan Pangan Produk Pindang Pada Umkm Pengolahan Ikan Rakyat. Jurnal PASTI (Penelitian dan Aplikasi Sistem dan Teknik Industri). 9(3):275-285.

Wahyuni, T., Nurliza, N., Kurniati, D. 2017. Preferensi konsumen terhadap pembelian kerupuk ikan di kota Sintang. Jurnal Social Economic of Agriculture (SEA). 6(1):101-108. http://dx.doi.org/10.26418/j.sea.v6i1.21592

Waluyo, E., Fuad, M.A.Z. 2014. IbM Industri Rumah Tangga Kerupuk Ikan dan Udang di Kec. Ujung Pangkah, Gresik. Laporan. Malang: Universitas Brawijaya. 